\title{
Radical Mobilities
}

\author{
Abstract \\ As mobility becomes a key concept within geography it needs to be considered what a \\ radical approach to mobility means. Reviewing literature on mobilities from within \\ transport, policy mobilities and migration studies, this article discusses three \\ interpretations of radical mobility: scale or speed of changes required in mobility, critical \\ approaches tracing mobilities and relations of power and approaches that question the \\ ontology of mobility. Drawing on material and radical black feminist thought, I instead \\ suggest a rhizomatic understanding of mobility as material-semiotic transformation of \\ energy. This ontology shifts understandings of what just and sustainable mobilities can \\ be.
}

Keywords: mobility, radical, black feminism, material feminism, power, justice, sustainability

\section{Introduction}

"If we want to transform or replace high carbon social practices, then we need to unmake the existing energy regimes in a more radical way"

(Sheller, 2017 in Temenos et al., 2017: 17)

Movements from Black Lives Matter to indigenous anti-pipeline movements and Extinction Rebellion have intervened in everyday mobilities on freeways (Avila, 2014), at borders, bridges, airports, ports (Cowen, 2014) and pipelines, in large part because these infrastructures maintain the (im)mobilities of business as usual. These movements and much mobilities research appear to share a clear message: Radical change in mobility is needed for futures that are more just and sustainable. But what does a radical approach to mobility imply and how does it differ from critical approaches?

Within studies of mobility 'radical' has been used to denote everything from speed and magnitude of change, to an overhaul of energy systems - portending very different visions of desired "alternative mobility futures" (Clarsen, 2018; Sheller, 2015). This paper reviews work in transport, migration and policy mobilities studies to clarify what is meant by radicality. I outline three interpretations of radicality and consider some of the risks to interpretations that imply only urgency, magnitude of change or automatically presume the radicality of particular forms of mobility. I argue it is necessary to follow critical approaches to mobilities in tracing and critiquing relations of power within which mobilities are imbricated and through which mobility, sustainability and justice are defined. However, remaining within critical frameworks of mobilities can risk being limited to modifying- or widening participation within - dominant racial-capitalist 
hierarchies of value, liberal notions of mobile subjectivity and mobility justice. I suggest, alongside material feminisms and radical black thought, that a radical approach entails a refusal of ontological divisions between materiality and meaning (Barad, 2010; Barad, 2013), racial-capitalist forms of valuation and liberal constructions of individualised subjectivity, freedom and blackness as a category of (devalued) difference (Ferreira da Silva, 2017a; Mbembe, 2018).

This paper suggests definitions of radicality within geographies of mobility. The wider question of what radical means in human geography has been debated for decades. It has been asked what radical geography has been (Peet, 2000; Peake and Sheppard, 2014), needs to be (283Collective, 2008; Esson et al., 2017; Chouinard, 1994) and must be (Gibson, 2014; Springer, 2014; Harvey, 2017). As mobility has become increasingly lauded as a core concept in geography as well as history and sociology (Clarsen, 2018: 114 ) there is a need to articulate more carefully what a radical mobility might mean. This is a complicated task, when mobility itself encompasses so disparate an array of practices, phenomena and processes from everyday movements of people and materials, to migration (Blunt, 2007; Gorman-Murray, 2009; King, 2012; Schapendonk et al., 2018), logistics (Cowen, 2014) and policy mobility (Peck, 2011). Conceptual framings vary when mobility is studied in sub-disciplines ranging from geography, sociology, social theory and public health to psychology, transport, media and communications, migration and policy studies (Clarsen, 2018).

As a paradigm of thought, it could be argued that the 'new mobilities paradigm' (Sheller and Urry, 2006) and precursors to this work on power and mobility (Massey, 1993; Cresswell, 1999; Cresswell, 1993; Creswell, 2006) was always intended to be radical. At its root, it was a transformative call aimed at sedentarist social science and its purported emphasis on fixed and bounded categories of analysis: Individuals, places, cities, communities, nations (Blunt, 2007; Hannam et al., 2006). The radicality of this move was understood as a shift towards a mobile metaphysics replacing 'roots' with 'routes' (Gustafson, 2001; Frello, 2008; Massey, 2005) recognising the (im)mobilities which constitute spaces, cultures, subjectivities and relations of power in a world increasingly on the move. Rather than take the radicality of the new mobilities paradigm as given, I argue there is a need to be more explicit about how the notion of radicality is employed and what theoretical understandings of mobility and power are relied upon. I do not aim to review the sheer breadth of mobilities literature, nor produce an exhaustive review of theories of power and mobility as these tasks have been taken up elsewhere (Schwanen, 2015c; Jensen, 2011; Doughty and Murray, 2016; Blunt, 2007; 2017; 2016; Cresswell, 2010a; 2012; 2014; Merriman, 2015; 2014; 2016). Instead, this paper focuses on the gaps and possibilities foreclosed when assumptions around mobility and power are left unquestioned.

Rather than presume particular movements, technologies, speeds or lineages of thought as inherently radical, I take a definition of radical that follows its etymology back to (rhizomatic) roots. As opposed to tree roots with a single taproot, rhizomes are subterranean networks constructed by bulbs and tubers which are simultaneously a food source and organs of asexual reproduction. Rhizomes are thus not fixed origins, but the 
(Deleuze and Guattari, 1987) processual networks of matter-meaning that constitute mobilities. This interpretation of radicality moves away from the search for a single structural determinant, origin or diagnosis of injustices and unsustainability of contemporary mobility, and towards seeing mobility as a form of power (Bærenholdt, 2013) enacted through material-semiotic metabolisms. I use this understanding of radicality both as an approach to reviewing literatures on mobilities - to map ontologies of mobility, theories of power and assumptions of value and subjectivity rooted within studies of mobilities and their effects (section I, II and III) and to suggest a particular political ontology of rhizomatic mobility (section IV). This radical rhizomatic approach draws on radical black thought and material feminisms to refuse binary divisions between materiality and meaning, the valued and devalued and thinks mobility otherwise; as a form of death or material-semiotic transformation of energy. Within this ontology of mobility, justice and sustainability become difficult to disentangle, and are not achieved after the fact through enhanced inclusion, modification of policy or circulations - but are immanent to mobility itself.

The paper is structured as follows: Section I discusses mobilities approaches in which radicality is understood as magnitude or speed of change, while largely leaving unquestioned the relations of power entangled in mobilities. In Section II, I turn to studies which critically assess how power relations structure mobility and yet do so largely to critique and explain the status quo rather than rethink the onto-epistemology of mobility. Section III outlines perspectives in which power is seen to operate through mobility and its very definition. In Section IV I outline a rhizomatic radical mobility: Remaking global mobility in this radical vein requires a refusal and reconfiguration of the root ontoepistemological presumptions of what mobility is, what and who is mobile, how and why (Schwanen (2017) in Temenos et al. (2017)).

\section{Radical in speed, scale or technology}

In this section I outline studies of mobilities in which the term radical is either automatically attached to particular technologies or is used to refer to the magnitude and speed of changes required to shift towards more sustainable and just mobility. In contrast to critical approaches to mobility (discussed in Section II) and approaches that question the ontology of mobility (in Section III) or rethink mobility otherwise (Section IV), there is little analysis or critique of how mobilities are imbricated in relations of power. Without this critical analysis, dominant understandings of mobility, sustainability, social difference and justice are presumed and 'radical' is employed as a shorthand to imply particular technologies, magnitudes, speeds or scale of change within largely the same paradigms of thought. There is a risk then of simply of maintaining - or only 'greening' and modifying somewhat - mobility systems that maintain possessive individualised, notions of subjectivity and freedom, racial-capitalist hierarchies of valuation and a division between materiality and meaning that imply silo understandings of sustainability and justice. 
Within transportation studies, for example, radical has been used to refer to the scale and speed of reductions in transport's impacts. Pollution, traffic accidents and physical inactivity associated with automobility are linked to increasing levels of mortality and disease (Woodcock et al., 2009; Sallis, 2016). With a quarter of global energy-related greenhouse gas emissions associated with transportation (Geels, 2012; Sims R., 2014; Creutzig et al., 2015) and the sector still predominantly dependent on fossil fuels, urgent and dramatic changes are required to mitigate a climate crisis. Calls for radical change then include everything from maintenance of a regime of private automobility but with 'radical changes' (Vergragt et al., 2017: 16); a revolution towards fully automated vehicles and mobility as service provision (McKinsey, 2019; Dhawan et al., 2019); transportation fuelled by $100 \%$ renewable energy systems (García-Olivares et al., 2018) or paradigm shifts including reducing the need for transport (Banister, 2008). It is clear that the word radical when used to imply the scale or speed of change, can imply substantively very different visions of future mobility.

There is, however, a militaristic hue to notions of urgent 'mobilizing!' (Pignarre and Stengers, 2011) risking TINA (there is no alternative) and techno-managerial solutions based on unquestioned definitions and assessments of the problem and its purported solutions. Urgency can create hierarchies between the immediately necessary - such as reducing emissions - and that which is relegated to the merely desirable (Olson, 2015) such as mobility justice (Mullen and Marsden, 2016; Sheller, 2018). As discussed in (Zavestoski and Agyeman, 2015) and (Golub et al., 2016), it is all too common to separate out understandings of sustainable mobility from mobility justice: the question of who carries the benefits and burdens associated with mobility. Advocating for slowing down and reductions in fossil-fuelled travel without consideration of social justice can make for regressive policies that are readily co-opted into neoliberal narratives around scarcity. These narratives justify what Nikolaeva et al. (2019) have called mobility austerity, cutting government funding and promoting individualised and community-level responsibility for reducing carbon emissions.

Approaches that take a socio-technical transitions approach (Temenos et al., 2017; Geels, 2014) or advocate for sustainable mobility paradigms (Banister, 2008) discuss radical changes in mobility systems and include reference to politics. However, power tends to be discussed within the given language and presumed understandings of the problem: Competing stakeholders, forms of leadership and public acceptability. Yet in many respects the relations of power embedded within policy prescriptions, definitions and evaluations (of public acceptability, for example) remains opaque. Where transitions theory attempts to tackle relations of power (Geels, 2014), power remains defined in relatively technocratic terms as something that actors use or have (Tyfield, 2014). The relations between practices and socio-technical regimes and transitions are theorized in terms of processes, practices and lock-ins understood in relatively mechanistic terms. Power as knowledge, ideologies, financing and resources, normalization or the ongoing violence or exploitation intertwined within mobility tend to be obscured. While sociotechnical transitions approaches have seldom focused on questions of social justice (Nikolaeva et al., 2019; Affolderbach and Schulz, 2015) more recent work has sought to bring transitions theory into closer conversation with work on social justice and the 
commons (Nikolaeva et al., 2019), and with research on governance within urban, economic geography and political ecology (Affolderbach and Schulz, 2015; Fastenrath and Braun, 2018; Lawhon and Murphy, 2012; Murphy, 2015).

There are a number of risks attached to research and interventions into mobility that omits a deeper analysis of power. Firstly, the production of knowledge about mobility risks reproducing harmful categorisations, narratives, relations of power and policies. For instance, Hatton (2018) argues that research within migration and refugee studies in the UK and Germany feeds into national policies of migration control, ultimately harming people migrating or seeking refuge. The production of knowledge about people labelled migrants and refugees, not only is reliant on increased government funding, associated with sets of policies instituting a 'hostile environment' (in the UK) it also reinforces the objectification of people migrating or seeking refuge, rather than questioning the structures of border control and surveillance that produce these categories. Similarly, perspectives on migration that uncritically rely on and reproduce categories such as expatriate and migrant, risk methodologically nationalist (Kunz, 2016) models which fail to adequately address wider racialized and (neo)colonial relations of power.

Secondly there is a risk of positioning a particular technology, mobility mode or policy intervention as essentially valuable and positive, without questioning its co-option within dominant relations of power, nor how these relations construct narratives and hierarchies of value. Some modes of transport such as cycling have been characterised as inherently radical or subversive, as less readily subsumed by state governance (Shell, 2018) or locked-in to flows of capital and oil and more aligned with anarchist and DIY cultures and practices (Furness, 2010; Shell, 2018). However in what has been called a 'totalizing' cycling advocacy (Cupples and Ridley, 2008) this mode of transport can also be co-opted into highly individualised, gendered, ableist and racialised narratives of health and sustainability.

An award-winning 2006 advertising campaign by Friends of the Earth Manchester, epitomizes some of these problems. The words fast lane are superimposed on the cycle lane and fat lane on the road, accompanied by the text: "burn calories, save cash, get there on time". The neoliberal discourse of cycling as the 'choice' of the healthy, slim, empowered, efficient, sustainable and financially responsible individual is reinforced, and the infrastructural and structural systems that differently enable, disable and harm cyclists are obfuscated. Gendered, fat-phobic, productivist, disabilist (Imrie, 2000), class-based and racialized hierarchies of value are simply reinscribed in the name of sustainable mobility. Critical mobility scholars have increasingly made this point, arguing that there is nothing inherently radical about cycling practice, advocacy and policy unless it questions the fields of power that produce it- characterized by spatial injustice, gentrification, white supremacy and neoliberal urban governmentality (Lugo, 2013b; Lugo, 2013a; Lugo, 2012; Stehlin, 2015; Stehlin, 2014; Lee, 2015; Golub et al., 2016; Golub, 2015; Stein, 2015; Spinney, 2016; Manderscheid, 2016).

Technological, infrastructural and behavioural interventions and policy tools that remain uncritical of the fields of power they are imbricated in, tend to default to a soft neoliberal 
consensus on mobility (Foucault, The Birth of Biopolitics, p. 84 as cited in Brown, 2015: 69). Soft neoliberalism (Peck, 2010), is the progressive, diverse, liberated, green and pink (Puar, 2006) face of neoliberalism where values of wellbeing, liveability and access are supposedly centred (Rajé and Saffrey, n.d.). Yet consensus remains on the economistic framings of success and teleological progress in mobility; towards logics of efficiency, economic growth, maintaining logics of debt and investment into presumed future growth. Successful mobility tends to be assessed and measured through universalized measures and monetized hierarchies, the aspiration being to enhance individual choice in a market of mobility. Discourses of scarcity (e.g. lack of funding, road space and the need to curb emissions) mean government-led initiatives are cut, and responsibility for mobility is shifted to individual, privatised or community-level responsibility (Nikolaeva et al., 2019).

A further risk of uncritical approaches is that dominant understandings of sustainability and justice and modes of accounting are presumed (O'Lear, 2016), and structures of governance (e.g. the state, policy frameworks, borders) are seen as a 'neutral force' (Pulido, 2016) or in need only of incremental reform. For example, to compare sustainability over time, space and mode of travel, supposedly objective and standardized definitions of sustainability - such as $\mathrm{CO} 2$ equivalent emissions - tend to be used (Hickman et al., 2013). However, emissions categorized by state, sector or particular technology (e.g. electric vehicles) risks overly-simplified silo prescriptions for sustainability through technological change and efficiency. Wider environmental impacts beyond tailpipe emissions (e.g. biodiversity loss) and the dispersed environmental and social impacts associated with extraction, production and waste remain hidden (Hickman and Banister, 2007). Overarching questions of social and environmental justice remain 'outside the scope' of calculation: Who benefits from particular narratives (Holden et al., 2019) or visions (Bergman et al., 2017) of sustainable mobility? Who has contributed to and benefited most from historic mobility-related emissions; who stands to profit from drives towards their reduction and who can financially, bodily, temporally afford to 'choose' not to move or to slow down? Equally, conceptions of mobility justice seen as separable from sustainability (Holden et al., 2019) risk ring-fencing too tightly the realm of ethical consideration. For example, where transport justice is defined narrowly as enhancing access to economic opportunity within a particular city or state, this excludes how economic growth could impact negatively on the lives, livelihoods and mobilities of those in other times and places.

Where health and societal impacts of mobility are accounted for, these tend to be measured in economic equivalences (GDP, disability-adjusted life years, health costs) and attached to relatively fixed social identity categories. Social justice is then operationalised as distribution of the benefits of mobility across categories. While this accounting may be necessary, it needs to be used to emphasise structural injustices rather than reify identity categories and their 'attributes'. For example, the under-representation of women in cycling and associated problematic notions of women as an indicator species (Peters, 2013; Pucher and Buehler, 2010) risks placing responsibility on women as individuals and using targeted behaviour-change programmes to encourage cycling. These programmes, however, fail to tackle underlying social, political, cultural and 
economic factors which may contribute to women cycling less, ranging from urban land use to gendered divisions of (household) labour and income and lack of flexible working hours (Smart et al., 2014; Huff and Ralph, 2014). This risks a reification of identity categories and an understanding of difference as an expanding palate of 'more of the same': Research initially conducted with affluent white mothers, for example, is seen to need reproducing with lower-income groups, fathers or same-sex families (Clement and Waitt, 2017). This risks a slippage in which "gender, race and migration status shape and distribute (im)mobility" (Kwan and Schwanen, 2016: 249) rather than ask how the very geographically specific hierarchies and techniques of categorisation within patriarchal racial capitalisms shape who and what is (understood as) able to move, why, how and with what attendant forms of violence.

\section{Radical or critical? Tracing \& critiquing power in mobilities}

In contrast to understandings of mobility discussed above, critical studies of mobility have increasingly sought to understand how movement is shaped by and entangled with relations of power (Nikolaeva et al., 2019; Robinson, 2015; Peck and Theodore, 2010; Söderström et al., 2013a; Beauchamps et al., 2017; Bissell, 2016; Blickstein, 2010; Cresswell, 2010b; Creswell, 2006; Cresswell, 1999; Sheller, 2018). Although the terms critical and radical have sometimes been used interchangeably (Peake and Sheppard, 2014) here I use 'critical' to refer to approaches that describe, diagnose and analyse relations of power. This work is vital in critiquing dominant visions (Bergman et al., 2017) and systems of mobility and their perpetuation of social and environmental injustices. In this section, I argue that while necessary, approaches remain critical rather than radical in scope when they maintain given ontological assumptions of what mobility is, presume relatively fixed or descriptive notions of power, scale and subjectivities and maintain dominant binary constructions of valued/devalued, failed/successful or just/unjust mobilities. It is impossible to do justice to the breadth and depth of critical work in mobilities studies. Below I highlight only some of the ways critical approaches miss opportunities to radically rethink the ontology of power and mobility and construct other ways of being, thinking, valuing and practicing just mobilities.

Critical studies of policy mobility emphasise the need not only to map the processes and places through which ideas move, but to understand the "forces that condition them" (McCann, 2011b: 122). In a similar vein, critical transport studies have asked how mobility policies, practices and experiences are shaped by, and help produce unequal and unjust cities. The dominance of private vehicles, for example, is not understood as a technical or procedural problem to be overcome through teleological advances in technology, policy or better individual choices, but as a system that both reinforces - and is constituted by - cultural, gendered, racialized, ideological, material, spatial and political-economic relations of power (Boehm et al., 2006; Conley and McLaren, 2009; Goodwin, 2010; Merriman, 2009; Pesses, 2010; Schwanen, 2015a; Urry, 2004; Walks, 2014). These relations of power are studied and critiqued to highlight injustices and 
unsustainability, identify their root causes (Uteng and Lucas, 2017), lock-ins (e.g. between land-use and mobility) and opportunities for contestation and resistance (Blanco et al., 2018). Bringing to light the ideological presumptions and values embedded in policy also paves the way for approaches to mobility based on different values and alternative visions of urban life (Chatterton, 2018). In the United States, Zavestoski and Agyeman (2015) ask: Whose perspectives, definitions and values around mobility in cities count? Who are infrastructures for? Whose needs and access - to work, education, health, social connection - are privileged? Writing about mobility in cities of the Global South, Uteng and Lucas (2017) argue urban transport policies must shift from a focus on infrastructure, to understanding mobility through human needs and as interlocking with socio-economic inequality, livelihoods, education and health.

Critical approaches vary in how they analyse relations of power within particular contexts of mobility: From understanding the mobility of policies as embedded in relations of power and particular ideologies (Peck and Theodore, 2010), political-economic power operating through neoliberal transport policies (Spinney, 2016), modernist ideologies valuing scientific rationality, efficiency and technological advance underpinning transport planning (Koglin, 2014; Koglin and Rye, 2014) through to understanding power using Foucaultian (Manderscheid, 2016; Manderscheid et al., 2014), material feminist and critical race theory (Stehlin, 2014; A. Nicholson and Sheller, 2016; Lugo, 2012; Lugo, 2013b; Lugo, 2013a; Stehlin, 2015). For some, these understandings of power are attached to particular scales; from the sub-bodily, affective or embodied mobility practice, to structural understandings of power (Doughty and Murray, 2016; Bærenholdt, 2013) and the macro level of urban, regional and national governance structures (Bissell, 2016). Drawing on Cresswell's (2010b) politics of mobility, for example, Hopkins et al. (2019) discuss academic mobilities as having a politics that occurs from the scale of the body (performances and experiences of mobility and the effects on the body of mobility), to familial ties and social networks and institutional rhythms.

Aside from a heuristic device to structure findings, these scalar divisions have also been used to highlight forms of mobility politics that remain relatively under-studied. Söderström et al. (2013b) and Manderscheid (2016) argue the micro level of individualized qualitative experiences of mobility has received more scholarly attention than structural understandings of power and mobility. This, Manderscheid (2016) argues, risks unwittingly reinforcing notions of the 'solitary mobile subject' - a perspective the mobility paradigm itself has attempted to unravel. Conversely, Walters (2018) posits that alongside the macro-politics of borders and sovereignty, the politics of migration needs to pay more attention to the microphysics - the informal techniques and sensory strategies used, for example, on deportation flights. Similarly, Bissell (2016) and Merriman (2018) use concepts from Deleuze and Guattari to draw attention to the molecular, as opposed to the molar (Merriman, 2018) and micro-politics as opposed to macro-politics (Bissell, 2016). These forms of power, they insist, are not at different scales as much as other levels of indeterminacy and perceptibility (Deleuze, 1988; Deleuze and Guattari, 1987).

However, parsing out forms of power and attaching them to particular scales, spatiotemporalities or to forms of determinacy or perceptibility (Merriman, 2018) runs the risk 
of mapping power in essentialised ways, rather than considering the political construction of scale (Jones et al., 2017; Silvey, 2004), legibility and fixity as itself a way in which power and mobility operate (Hyndman, 2013). Understanding power as that which enables or constrains mobility in a binary of mobility and immobility, creates a tendency to focus either on mobile subjects or state-level structures rather than how these are mutually constituted (Salter, 2013). This parsing out of power risks instituting hierarchies whereby some scales of analyses are deemed less political, less fundamental, radical or subversive or fluid than others. For example, rather than pitting analysis of the fluid micropolitics of encounter in stark opposition to supposedly rigid identities and subjectbound social formations of class, race, gender or ability, it is important to highlight how mobile encounters, bodies and spaces configure one another in both highly visible and imperceptible ways through gendered, ableist, racialized and political-economic relations of power (Imrie, 2000; Silvey, 2004; Walsh et al., 2013).

Writings on affect within literature and critical race and feminist theory (Berlant, 2011; Rankine, 2015; Pedwell and Whitehead, 2012; Ahmed, 2015), attest to how affect is deeply political and structural even if and when it operates below the level of human cognition. Referring to these as micro - in opposition to the structural - risks denying their mutual imbrications. The work of feminist migration studies has been particularly important in highlighting how gendered and racialized subjectivities are not fixed identities, but are constituted through forms of mobility and immobility (Elliot, 2016; Blunt, 2007). Taking the work of queer, disability/crip and critical race theory seriously, means considering how these relations of power configure the very categories and modes of thought, matter and (de)valuation of legible and legitimate mobility and humanness (Wynter, 2003).

Within studies of everyday urban mobility and policy mobilities terms such as circulation (Salter, 2013), infrastructure (Lugo, 2013b; Lugo, 2013a) and assemblage (McCann, 2011a; Baker and McGuirk, 2016; Rink and Gamedze, 2015; Salter, 2013; Waitt and Welland, 2017) have been employed to help decentre the mobility/immobility binary, avoid reifying scales (Affolderbach and Schulz, 2015) and shift focus from the (im)mobile subject, item, policy or idea and towards the dynamic, complex discursive and material relations of power in which mobility is imbricated. Robinson (2015), for example, argues for a topological conception of policy mobilities to understand the complexities of flow, incorporation and adaptation of policy ideas. The term assemblage has been used to describe policy models (Temenos and McCann, 2013), the 'actors, materials, processes, and practices' involved in the movement of policies as well as a particular methodology for undertaking critical policy research (Baker and McGuirk, 2016: 429).

The notion of assemblage has also been used in research on the experience of everyday mobilities which draws on new materialism and material feminism (Boyer and Spinney, 2016; Doughty and Murray, 2016; Clement and Waitt, 2017). This work emphasises how discourse and material embodiment are a 'two-way interaction' (Doughty and Murray, 2016) in which, for example, "mothers and babies, prams and other actors and actants" (Boyer and Spinney, 2016) meet as assemblages. Both subjectivity and mobility (Boyer 
and Spinney, 2016) becomes through "entanglements with bodies and materials alongside ideas, emotions and affects" (Clement and Waitt, 2017; Boyer and Spinney, 2016). It is helpful to elucidate how both things and ideas matter in the experience of mobile motherhood, for example. However, the term assemblage is used here largely to refer to a collection of things and meanings (Clement and Waitt, 2017: 1187) rather than taking assemblage as a concept (Anderson and McFarlane, 2011) to question the ontology of mobility, motherhood as an 'identity' and the very division between the material and the discursive (Puar, 2011).

Similarly, the common use of verbs like examine, explore, describe, explain (Lovell, 2019) discern, disentangle, interpret, analyse and investigate (e.g in Baker and McGuirk, 2016) used to describe the work of policy mobilities, imply a focus on describing and understanding the existing processes and power relations of policy mobility. However, Prince (2017: 337) argues that assemblage thinking offers policy mobilities an approach to that goes beyond description to ask what barriers, ideologies and hierarchies make particular movements of policy possible. In this respect, contemporary policy mobilities certainly go beyond 'endless description' (Allen, 2011: as cited in Prince (2017)) to offer important resistance to the forms of neo-colonial (Wood, 2015) and neoliberal spatialities, ideological assumptions and practices through which 'successful' and 'failed' (Lovell, 2019) policies move or stall. While deeply critical (in both senses of the word), I argue this work is not radical in terms of refusing dominant ontological presumptions of what mobility is, the determination of subjectivity and value ${ }^{i}$ and the ways in which mobilities can be thought. Using assemblage primarily as a tool in the description, diagnosis and critique of the present, is quite different from constructing ontologies that anticipate other ethics and futures (Colebrook, 2000: 90).

\section{Redefining mobility: Towards radical ontologies?}

In this section I turn to mobility studies which have sought to rethink the ontology of mobility, and the relations of power that construct who and what is understood to be mobile (Manderscheid et al., 2014; Frello, 2008; Sheller, 2015). I argue that rethinking the ontology of mobility - for example, through understanding (policy) mobilities as assemblages - is generative to new avenues for understanding how power operates as and through mobility. However, I raise concerns about the political implications of particular mobile ontologies: Firstly, approaches have begun to question the division between the material fact of movement and its representation but have risked understanding mobility as entirely discursively constituted or have taken an additive approach, in which mobility is understood as both matter and meaning. In both cases the division between materiality and meaning is maintained and their mutual imbrication is not fully explored. Secondly, while a focus on non-representational mobilities opens up to wider understandings of power, there is a risk of being less able to speak to - and disrupt - mobility as an expression or technique of imperial white-supremacist capitalist and disablist patriarchal (hooks, 2003) power. 
Frello (2008) has questioned the division between the 'brute fact' of mobility and its representation. As highlighted above, some uses of the term assemblage describe the movement of ideas as an addition to, or a layer on top of, the physical fact of movement. Cresswell (2013) discusses people as "fleshy human bodies in the material world" (p. 81) as well as "figures in a representational landscape" (p. 82). However, for Frello (2008), there is no such thing as the physical fact of movement. What counts as mobile is a discursive construction and an effect of power. Yet, perhaps due to the theoretical lineages employed, Frello (2008) risks attaching power within mobility solely to the discursive. The materialities of fossil fuels, documents, walls, wire, heat, water or pollution risk being constructed as powerless without having meanings to animate them. It is important to draw on material feminism here to highlight how the fleshy human bodies Cresswell (2013) writes of are always figured, and representational figures are always enfleshed. In other words; the very becoming of fleshy humans cannot be understood outside of heterosexist, colonial, gendered, racialized, disableist infrastructures (think of access to clean water, food, healthcare, shelter, livelihoods, absence of violence). Further, in line with radical black thought (McKittrick, 2015a; Wynter, 2003; Wynter, 2001; Mignolo, 2015; Weheliye, 2014; McKittrick, 2015b; McKittrick, 2017), the figure of the Human - of the responsible, valued, individual mobile person - is not an abstract neutral body, but is enfleshed in very particularly racialized (as well as gendered, sexualized, classed and capacitated) ways.

Drawing on similar theoretical influences as material feminism and new materialisms (Deleuze, 1994; Deleuze, 1992; Deleuze, 1988; Deleuze and Guattari, 1987) postphenomenological (Ash and Simpson, 2016) and non-representational theories (Dewsbury and Thrift, 2005) have taken a 'radically processual' (Merriman, 2018) approach to understanding mobilities, asking what a body can do, rather than what it is (Bissell, 2010a). In an effort to move away from a politics of mobility that centres on "rigid social formations" (Bissell, 2016) of given subjects or identities, these approaches consider the pre-cognitive, immanent forces within (im)mobility. This aligns with views in which mobility itself is an operation or technique of power (Bærenholdt, 2013), rather than a fact of displacement which is then enabled or controlled (Beauchamps et al., 2017) and given meaning through power. This allows for important understandings of how mobility constitutes subjectivities and how these could be remade in creative ways within politics understood as more than simply institutional or structural.

However, there is a risk in creating a new binary and hierarchy between the nonrepresentational (or pre-discursive) and representational (discursive), within which bodily difference is understood as a representational identity politics, and supposedly, an unsatisfactory starting point for analysis. As pointed out by Nash (2000) this risks effacing embodied difference and theorising embodiment as an abstracted, universalised, blank-slate. Alternatively, affective experience is narrated from a singular body without elucidating their historical and contextual material-ideological, embodied affordances: The role of masculinity, whiteness and wealth in making desirable and possible various forms of mobility (e.g. a multi-day walk (Wylie, 2005) or urban exploration (Garrett, 2014; Garrett and Hawkins, 2013; Mott and Roberts, 2013b; Mott and Roberts, 2013a). While feminist migration and mobility studies (Hyndman, 2013; Akyelken, 2013; 
Scholten et al., 2012; Uteng, 2009; Walsh et al., 2013) focus on how mobilities are structured, experienced and understood through axes of power tied to embodied difference, this is still less prevalent within mobilities research (Sheller, 2015: 16) and considered marginal within migration studies (Nawyn, 2010).

When approaches to mobility shy away from discussions of power operating through the state, capital, gender, sexuality or racialisation there is a risk of being left with a notion of power that has 'little purchase' (Adey, 2006: 76). While it is necessary to move away from a focus on singular agentic sovereign (human) mobile bodies (Merriman, 2018), and to take seriously how all mobility - from vibrations (Bissell, 2010b) to elements in infrastructures (McCormack, 2017) - are political (Adey (2010b, 131, in (Bissell, 2016)), concepts are needed that can name how mobility infrastructures, policies and patterns configure violence, values, hierarchies and particular understandings of what it means to be human.

Naming relations of power does not have to mean slipping into fixed, structural perspectives on power but can mean considering, as Anderson (2017: 501) does; "how relations of domination, coercion, instruction and so on emerge through the assembling of worlds..." (Anderson, 2017: 501). Within an immanent understanding, capitalist-imperial power, for example, emerges through borders (Mbembe, 2018; Anderson et al., 2009; Burridge, 2014), surveillance and immigration policy (Schapendonk et al., 2018) as well as policing and incarceration (Burridge, 2014). Rather than applying a particularMarxist, non-representational, feminist or queer - lens or logic to trace or understand mobility, this means understanding (im)mobility as an expression and technique of particular intensities and forms of power (Anderson, 2017). Radical forms of - and approaches to - mobility are then not romanticized alternatives exterior to existing relations of power (Kirby, 2011: 113), but are emergent from within 'globalization, the carceral state, and empire' (Cowen, 2014: 224). In Cowen's (2014) work on logistics, drawing on Puar (2005), this means recognising how the worlds of logistics are queer, and subversion of these circulations is made possible through the same colonial, racialized and militaristic mobilities it seeks to disrupt.

\section{Radical mobilities as rhizomatic}

"The crux of this exercise is to provide an account of opposition that

figures nullification instead of contradiction. This is crucial for distinguishing a radical engagement from a critical one-because the latter cannot but assume the Kantian forms when it seeks to expose their conditions of possibility."

(Ferreira da Silva, 2017a: 9)

Harney and Moten (2013) distinguish between the abolition of slavery, and the "abolition of a society that could have prisons, that could have slavery, that could have the wage" 
(p. 42). In this section I follow a definition of radicalism that follows abolitionist thought (Gilmore, 2017), Ferreira da Silva's quote and radical black feminist thought that goes beyond a call for inclusion into - or modifications and improvement of - imperialist white-supremacist capitalist patriarchy (hooks, 2003). Instead, radical black thought calls for ways of studying (Gilmore, 2017; Harney and Moten, 2013) and practicing freedom that do not rely on normative, western-centric liberal presumptions and hierarchies of subjectivity, value and justice. In this section I consider what such an approach to radicality might mean for human geographies of mobility. I distinguish radical approaches from those that remain uncritical of relations of power and argue for less, more or improved technologies of mobility (section I); critical approaches that seek to understand mobility and power (section II) or rethink mobile ontologies (section III) but maintain divisions between scales of power, materiality and meaning or risk being unable to speak to how ontologies of mobility are racialized, gendered and disablist. A radical mobility calls for the abolition of societies in which the configuration of (im)mobility is a technique and expression of systemic oppression. What I call a rhizomatic radical mobility might require a nullification (Ferreira Da Silva, 2017b) of fundamental divisions between meaning and materiality; liberal definitions of mobile subjectivity, value and justice and be based an understanding of how material-semiotic violence (and justice) are embedded within ontologies of mobility.

Below, I suggest an ontology in which mobility is understood as material-semiotic transformations of energy. This approach is rhizomatic in that it recognises what already exists and is already in process underground. As Harney and Moten (2013) put it, other worlds are already in the process of being planned within subaltern undercommons. These may be the 'last places they thought of' (McKittrick, 2014) and within epistemologies that do not adhere to, or require, core premises (objectivity, universality) and techniques (measurement, classification, interpretation) of modern knowledge production (Ferreira Da Silva, 2013: 44). This ontology is rhizomatic also in that it looks to expose the socio-material exhaustions and transformations that are mobility's conditions of possibility. For radical geographies of mobility this means not seeking a single or fixed structural root determinant of mobility, but mapping (Deleuze and Guattari, 1987) the meanings-materialities (rhizomes) that configure it. It also brings a shift in focus from moving subjects, objects and ideas themselves towards the relational material-semiotic processes involved in mobility as an operation of power.

Most forms of human movement require transformation of energy through death and/or the foregoing of forms of life. Energy derived from fossil fuels requires the burning of organisms that died millions of years ago and supposedly 'human'-powered mobility is always more-than-human (Whatmore, 2013) in that it requires the metabolism of plant, animal, insect or microbial lives or the agents of their reproduction (seeds, fruits) to produce energy ${ }^{\text {ii }}$. This is material-semiotic in that it is both a biophysical transformation and entangled with ideas (Haraway, 2004). The use and combustion of fossil fuels for energy, for example, can't be extracted from histories, ideologies and practices of the industrial revolution, chattel slavery, colonisation, white supremacy, capital circulation and exploitation of labour (Boyer, 2017; Clark and Yusoff, 2014; Szeman and Boyer, 2017). The movement and generation of what we might think of as human ideas are also 
subtended by energetic and material relations (Bosworth, 2016; Clark and Yusoff, 2014). Below I outline some implications this ontology might have for how geographers can understand mobile subjectivity, the value(s) of mobility and mobility justice.

\section{Subjects of mobility}

Understanding mobility as material-semiotic energetic transformation decentres the mobile subject, without obscuring or denying the material-discursive relations of power that constitute it. A person walking, for example, is constituted by biophysical and discursive processes that rely on and produce - yet also defy - the boundaries of skin and the legally and medically recognized limits of personhood. They are constituted with and through the transformation of energies and bodies: energy, data and materials in a smart phone translated into walking directions, caffeine transformed into the sensation of energy and topography and gravity transforming muscles. This speaks to intra-action (Colls, 2007; Barad, 2007) in co-constitutive becoming and to a non-relational politics of mobility, where power is not always and only understood as human. The capacities, configurations and attributes of materials, apps (Schwanen, 2015b) or fossil fuels may have particular tendencies and portend futures that do not include the human, yet configure what forms of mobility are possible. In other words, a rhizomatically radical mobility may need to care about things that don't give a shit about us (Hird and Clark, 2013).

This does not mean advocating an entirely posthuman understanding of subjectivity (for a discussion of some of the problems in this approach, see Weheliye, 2014). The mobile subjects of migration studies, policy mobilities or transport studies are configured within racialized, gendered and ableist understandings and hierarchies of the human and of normality and desired subjectivity. These hierarchies are designed-for, encoded and disciplined into laws, products, policies, surveillance, infrastructures, extraction (Yusoff, 2018) and flows of energy, capital and constitutive parts of bodies (Povinelli, 2006; Dixon, 2014). The very conditions of possibility for embodiment - food, safety from damaging environments and (state) violence, access to forms of status and recognition, finances, healthcare, clothing, housing - are configured through hierarchies of humanness. As Sylvia Wynter argues, stories of valued humanity become embedded into the very neurological encodings of experienced pleasure and pain (Wynter, 2003). A radical mobility needs to recognise how deeply racialized, ableist and gendered narratives of humanity inherited through colonial modes of knowing (Mignolo, 2015; Jackson, 2013; Weheliye, 2014) are expressed as, and reproduced through, mobility.

A rhizomatic approach to mobility would not aim for inclusion or recognition of marginalised categories of subjectivity within dominant (patriarchal and racist) notions of valued mobility and humanity (Mignolo, 2015: 119). Ferreira da Silva (2017a) writes that an understanding of "blackness as a category of difference... functions as a signifier of violence". Similarly, Ansfield (2015), writing about urban reconstruction in post-Katrina New Orleans, points out that tying lack of network capital or motility to race fixes into place dominant tropes of black pathology, if there is no recognition of the wider 
racialized constructions of valued mobility and humanness (Ansfield, 2015: 133). Rather than linking devalued (im)mobility to bodies and/or spaces marked as female, black, poor, queer, disabled or disadvantaged, a radical perspective needs to question the modes of thought which require the construction of categories of recognized, valued humans, and the modes of analysis that seek to understand determining relations between these categories and mobility outcomes (Ferreira da Silva, 2017a). Rather than see difference as essentialised categories or identities performed within particular 'intercorporeal situations' (Saldanha, 2016), difference might be understood as an indeterminate, emergent material-semiotic force (Grosz, 2012) which is constructed and expressed through power as mobility.

\section{Valuing mobility}

Within contemporary hierarchies of value it may be that "mastering of movement is a resource" (Frello, 2008: 34). However, mobility studies risk reinforcing dominant modes of valuation when they do not question the tenets of thought, presumptions and relations of power that constitute value. Advocating for inclusion or more equitable distribution of mobility might seem a necessary fix, but it does not destabilise the presumption that movement is a resource of which 'mastery' is desirable. A rhizomatic approach might instead consider how value is constructed and transformed as and through mobility: For example, in the process of transforming value from slave labour and native lands into movements of contemporary global capital (Ferreira Da Silva, 2017b). Further, a rhizomatic approach might question how mobility theories, practices, infrastructures and discourses reinforce binaries of value in which capability, freedom, wealth, choice and mobility, life, novelty, discovery, innovation, whiteness, masculinity, health (and its supposed-imageries of youth, thinness, speed, attractiveness, fitness) and sustainability and imaginaries of efficiency, cleanliness, whiteness, wholeness, life, longevity and order - are valued and their antonyms are associated with the negation of value. Understanding mobility as always already a socio-material energetic transformation, such as in the weatherings (Neimanis and Walker, 2014) and wearing down of moving parts, the use of energy in digital mobility (Gabrys, 2014) the tearing of muscle tissues (Acker, 1993), makes it less tenable to think of particular forms of mobility, flux or nomadism (Braidotti, 2011) as inherently more healthy, sustainable, progressive and valuable. Instead, mobility is understood to configure forms of "precarity and (un)liveability" (Puar, 2017) and indistinct zones between life and death (Weheliye, 2014; Povinelli, 2006). This does not mean flipping the script and valorizing the devalued but questioning the role (understandings of) mobility play in reinforcing hierarchies of value.

A rhizomatic approach to mobility also belies a predominantly political economic understanding in which value is framed largely through the presence or absence of capital (Ferreira da Silva, 2017a). Reducing valuation to a function of political economy or social or cultural meanings, denies how power is also enacted through flows and obduracies of energy and non-living materiality understood as the 'geo' (Whatmore, 2013; Povinelli, 2016). Electricity, walls, ships, airports or bicycles are not simply inert 
vessels waiting to be filled with human, socially-constructed value (Grosz, 2017) but themselves contain socio-material obduracies and openings. Automobility in the United States, for example, needs to understood not only as a social, political and economic phenomenon, but also through the energy density of oil and the forms of material and semiotic power mobilized and exhausted by it (Huber, 2013).

\section{Mobility justice}

Research reviewing different perspectives on mobility justice (e.g Pereira et al., 2016; Sheller, 2018; Lucas et al., 2015) shows how particular roots/routes for understanding justice imply quite different approaches and interventions into mobility. How mobility is understood - whether as migration or transport, a resource, an amalgam of movement, practice and meaning (Cresswell, 2010b) a commons (Nikolaeva et al., 2019), an enfolding life-path (King, 2012) - or as I have suggested here - a transformation of material-semiotic energy, will also have implications for how mobility justice is imagined.

Transport justice, for example, has tended to understand mobility in terms of its burdens (financial cost, risks, time and health exposures) or its social and individual utility (access to jobs, social connection, health, goods and services). Lack of access is understood as transport poverty (Lucas, 2004; Lucas et al., 2016; Martens, 2012) with transport justice seeking to ensure that values and costs of mobility are more equitably distributed amongst social groups understood through categories of race, income, age and gender (Blumenberg, 2008; Blumenberg and Ong, 2001). Theoretically, there has been a predominance within transportation studies of liberal conceptions of distributive justice (e.g. Rawls, as discussed in Pereira et al. (2016)). Liberal justice has also been common within geographies of migration, in which injustice is understood as transgression of individual rights (Banai et al., 2012), unfree or forced movement, victimhood (King, 2012) and justice as varying expressions of freedom from oppression and constraint to movement.

The "bounded utilitarian individualism" (Haraway, 2016) of liberal justice presumes isolated rational, normalised individuals. Feminist and critical race theorists have pointed out (Mills, 2017) the impossibility of a 'blank slate' subject which erases difference, entangled affective contagions, habits, traumas, dependencies and historically and spatially dispersed forms of power and oppression. Further, materiality tends to be presumed as a backdrop or resource for production of value or a sink for externalities largely a vehicle for achieving human ends, reinforcing a human/environment binary. The spheres within which principles of justice such as egalitarianism or sufficientarianism (Lucas et al., 2015) apply, is a human one, tied to a given political territory, subjects or policy spheres bounded in space and time, leaving little room for conceptualizations of justice that transgress political boundaries and divisions between presents/futures and humans/environments. Framing itself as universal, Eurocentric 
liberal thought obscures how liberal conceptions of justice, freedom and progress are implicated in - and reliant upon - racial capitalism, slavery and empire (Gopal, 2019: 15).

In Mobility Justice, Sheller (2018) outlines a wide-ranging, multi-scalar notion of mobility justice (p.35) which goes beyond the limits of both liberal transport justice and more immobile spatial justice. Sheller (2018: 170) advocates for a mobility commons that draws on Global South, indigenous, feminist and queer thought and breaks down the boundaries between humans and more-than-humans. For Sheller (2018), the idea of a mobile commons brings mobility away from individualised, private ownership and the restrictions of capitalism and borders (p. 169). Yet the operationalisation of a mobile commons still speaks to the distribution of mobility as a possession requiring distribution, with the state functioning to regulate corporations, excessive mobility and speed and preventing harms of mobility (p. 169). I would argue that understanding mobility as a process of energetic transformation, rather than a thing or resource to be owned, used or distributed, requires a shift in how mobility justice is understood. Mobility understood as always-already a form of power, a material-semiotic death and transformation, has an ethics that is practiced into becoming. For example, ethics do not only come into play in the distribution of access to fossil fuels or the uneven effects of climate change, but in the very acts of extraction and burning - and the material-semiotic relations this transforms. This aligns with understandings of justice in the work of feminist philosophers such as Barad (2010), Grosz (2017) and Ferreira Da Silva (2013) drawing on Derrida's 'justice to come': Justice is immanent to mobility's ontology (Grosz, 2017) rather than a result of its distribution or a particular desired end point fulfilled through thought experiments or moralities and their "maxims and prescriptions" (Butler and Athanasiou, 2013).

When mobility is always already an entangled process of meanings and materialities, it becomes difficult to disentangle where sustainability ends and justice begins. The act of renting and driving a car, for example, represents a mobilising of material-semiotic energies and resources (driver's licence, legal status, money, language, fossil fuels) which create particular worlds and foreclose other worlds. Questions become less about whether particular forms of mobility are just or sustainable, but about which sociomaterial configurations are enabled and exhausted, how and with what effect. In practice, sustainable mobility might look less like Malthusian maxims to travel less; accounting for and distributing fair carbon footprints or incentivising individual travel behaviours. Sustainability might look like justice, and both may be more about staying with what Ferreira Da Silva (2013) calls a radical praxis of exposing the "constitutive violence" through modes of "affection, intention and attention" (p. 59). Configurations of mobility that rely on - and facilitate - large scale destruction of ecosystems, expropriation of land and exploitation of labouring bodies and livelihoods, cannot be fixed (Halberstam, 2013; Harney and Moten, 2013). Instead, mobility justice might need radically other ways of configuring and valuing mobility (Sheller, 2018) and humanness itself (McKittrick, 2015b).

\section{Byways of conclusion}


"Failure's byways are all the spaces in between the superhighways of capital"

(Halberstam, 2011: 19)

Radical mobilities - both the configurations mobilities take, and their study - may look like disruption or failure, or may not be recognised as being (about) mobility within dominant ontologies and registers of value. Thinking about mobility across migration studies, transport and policy mobility invites questioning of the ontology of mobility and a cross-pollination across different ways of studying mobility (Kwan and Schwanen, 2016). King (2012) has suggested the mobilities paradigm helped shift migration studies away from fundamental divisions between forms of migration and towards understandings of a common mobility. Critiques of borders and state power from within migration studies, in turn, could inform a body of research on everyday urban mobilities that is more critical of the role of policy (Harney and Moten, 2013: 74). This is not about accumulating ways of understanding mobility but about making transparent, understanding and challenging divergent and shared assumptions: What is mobility understood to be? What are the presumptions made of a mobile subject? What hierarchies of value are presumed and what definitions of sustainability and justice are employed?

Only through being transparent about our own assumptions about power and mobility can human geographies of mobility be clear about what is meant by radicality. Here I outlined three common approaches: Firstly, using the term radical to imply magnitude and scale of change required for transitions to more just and sustainable mobilities. While speed and magnitude of change is necessary, these approaches tend not to acknowledge relations of power embedded within and enacted by mobility. Second, I outlined necessary critical approaches to mobility which trace the relations of power that structure (im)mobilities, but often maintain divisions between discursive and infrastructural power and tend to presume given ontologies of mobility. Third, I considered approaches that question the politics of what it means to be mobile and how this is defined. Lastly, drawing on radical black and material feminist thought that unsettles liberal conceptions of the subject, value and justice, I proposed an understanding of radicality as rhizomatic. This asks very different questions of mobility, namely: What are the material-semiotic deaths or transformations of energy it enacts, requires and produces? When mobility is understood to be the manifestation of forms of death or transformation, the value of particular forms, ideologies, distributions or technologies of mobility cannot automatically or universally be presumed. Rather, questions of ethics and mobility need to be specific, process-based and material-semiotic: How does mobility configure particular worlds? What and who is exhausted or transformed in the process? Sustainability and justice of mobility, in this framing, cannot be addressed separately.

Further, taking a rhizomatic approach to human geography research on mobility itself, we might ask ourselves where ideological-energetic resources accumulate, which flows of ideas are reproduced, exploited, exhausted and transformed in the process? What possible worlds are mobilized, condoned and upheld, silenced or deemed to have failed? This paper provokes human geographers not only to 'unmake mobilities' (Sheller, 2018; 
Temenos et al., 2017) but also to unlearn the onto-epistemological assumptions hierarchies of value, modes of subjectification and material-semiotic configurations through which power-as-mobility operates. Without unravelling mobility in this way, future imaginings and practices of mobility risk serving to sustain the status quo, albeit in various hues of white-washed green.

\section{References}

283Collective. (2008) What's Just? Afterthoughts on the Summer Institute in the Geographies of Justice 2007. Antipode 40: 736-750.

A. Nicholson J and Sheller M. (2016) Race and the Politics of Mobility: Introduction.

Acker K. (1993) Against ordinary language: the language of the body. In: Kroker M (ed) The last sex : feminism and outlaw bodies. Basingstoke: Basingstoke : Macmillan, 20-28.

Adey P. (2006) If Mobility is Everything Then it is Nothing: Towards a Relational Politics of (Im)mobilities. Mobilities 1: 75-94.

Affolderbach J and Schulz C. (2015) Mobile transitions: Exploring synergies for urban sustainability research. Urban Studies 53: 1942-1957.

Ahmed S. (2015) The cultural politics of emotion, Edinburgh: Edinburgh University Press.

Akyelken N. (2013) Development and Gendered Mobilities: Narratives from the Women of Mardin, Turkey. Mobilities 8: 424-439.

Allen J. (2011) Powerful assemblages? Area 43: 154-157.

Anderson B. (2017) Cultural geography i: Intensities and forms of power. Progress in Human Geography 41.

Anderson B and McFarlane C. (2011) Assemblage and geography. Area 43: 124-127.

Anderson B, Sharma N and Wright C. (2009) Editorial: Why No Borders? Refuge 26: 518.

Ansfield B. (2015) Still Submerged: The Uninhabitability of Urban Redevelopment. In: McKittrick K (ed) Sylvia Wynter: On Being Human as Praxis. Durham and London: Duke University Press, 124-141.

Ash J and Simpson P. (2016) Geography and post-phenomenology. Progress in Human Geography 40: 48-66.

Avila E. (2014) The Freeway Is the Perfect Place to Protest Ferguson. Available at: http://www.zocalopublicsquare.org/2014/12/15/the-freeway-is-the-perfect-placeto-protest-ferguson/ideas/nexus/.

Bærenholdt JO. (2013) Governmobility: The Powers of Mobility. Mobilities 8: 20-34.

Baker T and McGuirk P. (2016) Assemblage thinking as methodology: commitments and practices for critical policy research. Territory, Politics, Governance 5: 425-442.

Banai A, Lenard PT and Torressi T. (2012) Migration and Global Justice. Global Justice: Theory Practice Rhetoric 5: 1-3.

Banister D. (2008) The sustainable mobility paradigm. Transport Policy 15: 73-80.

Barad K. (2007) Meeting the Universe Halfway: Quantum Physics and the Entanglement of Matter and Meaning, Durham and London: Duke University Press. 
Barad K. (2010) Quantum Entanglements and Hauntological Relations of Inheritance: Dis/continuities, SpaceTime Enfoldings, and Justice-to-Come. Derrida Today 3: 240-268.

Barad K. (2013) On Touching--The Inhuman That Therefore I Am. differences 23: 206223.

Beauchamps M, Hoijtink M, Leese M, et al. (2017) Introduction: Security/Mobility and the politics of movement. In: Leese M and Wittendorp S (eds) Security/Mobility: Politics of Movement. Manchester: Manchester University Press.

Bergman N, Schwanen T and Sovacool BK. (2017) Imagined people, behaviour and future mobility: Insights from visions of electric vehicles and car clubs in the United Kingdom. Transport Policy 59: 165-173.

Berlant L. (2011) Cruel Optimism, Durham, NC: Duke University Press.

Bissell D. (2010a) Passenger mobilities: affective atmospheres and the sociality of public transport. Environment and Planning D: Society and Space 28: 270-289.

Bissell D. (2010b) Vibrating materialities: mobility-body-technology relations. Area 42: 479-486.

Bissell D. (2016) Micropolitics of mobility: Public transport commuting and everyday encounters with forces of enablement and constraint. Annals of the American Association of Geographers 106: 394-403.

Blanco J, Lucas K, Schafran A, et al. (2018) Contested mobilities in the Latin American context. Journal of Transport Geography 67: 73-75.

Blickstein SG. (2010) Automobility and the Politics of Bicycling in New York City. International Journal of Urban and Regional Research 34: 886-905.

Blumenberg E. (2008) Immigrants and transport barriers to employment: The case of Southeast Asian welfare recipients in California. Transport Policy 15: 33-42.

Blumenberg E and Ong P. (2001) Cars, Buses, and Jobs: Welfare Participants and Employment Access in Los Angeles. Transportation Research Record 1756: 2231.

Blunt A. (2007) Cultural geographies of migration: mobility, transnationality and diaspora. Progress in Human Geography 31: 684-694.

Boehm S, Jones C, Land C, et al. (2006) Against Automobility. Malden, Oxford: Blackwell.

Bosworth K. (2016) Thinking permeable matter through feminist geophilosophy: Environmental knowledge controversy and the materiality of hydrogeologic processes. Environment and Planning D: Society and Space.

Boyer D. (2017) Energopower: An Introduction. In: Szeman I and Boyer D (eds) Energy Humanities. Baltimore: Johns Hopkins University, 184-205.

Boyer K and Spinney J. (2016) Motherhood, mobility and materiality: Material entanglements, journey-making and the process of 'becoming mother.

Environment and Planning D: Society and Space 34: 1113-1131.

Braidotti R. (2011) Nomadic Subjects: Embodiment and Sexual Difference in Contemporary Feminist Theory, New York: Columbia University Press.

Brown W. (2015) Undoing the demos : neoliberalism's stealth revolution: New York: Zone Books.

Burridge A. (2014) 'No Borders' as a Critical Politics of Mobility and Migration. ACME: An International E-Journal for Critical Geographies 13: 463-470. 
Butler J and Athanasiou A. (2013) Dispossession: The Performative in the Political, Cambridge: Polity Press.

Chatterton P. (2018) Unlocking Sustainable Cities: A Manifesto for Real Change, GB: Pluto Press.

Chouinard V. (1994) Reinventing Radical Geography: Is All That's Left Right? Environment and Planning D: Society and Space 12: 2-6.

Clark N and Yusoff K. (2014) Combustion and Society: A Fire-Centred History of Energy Use. Theory, Culture \& Society.

Clarsen G. (2018) Vistas of Future New Mobility Studies. Transfers 8.

Clement S and Waitt G. (2017) Walking, mothering and care: a sensory ethnography of journeying on-foot with children in Wollongong, Australia. Gender, Place \& Culture 24: 1185-1203.

Colebrook C. (2000) From Radical Representations to Corporeal Becomings: The Feminist Philosophy of Lloyd, Grosz, and Gatens. Hypatia 15: 76-93.

Colls R. (2007) Materialising bodily matter: Intra- action and the embodiment of 'Fat'. Geoforum 38: 353-365.

Conley J and McLaren A. (2009) Car Troubles: Critical Studies of Automobility and auto-mobility Farnham: Ashgate.

Cowen D. (2014) The deadly life of logistics: mapping the violence of global trade, Minneapolis, Minnesota: University of Minnesota Press.

Cresswell T. (1993) Mobility as Resistance: A Geographical Reading of Kerouac's 'On the Road'. Transactions of the Institute of British Geographers 18: 249-262.

Cresswell T. (1999) Embodiment, Power and the Politics of Mobility: The Case of Female Tramps and Hobos. Transactions of the Institute of British Geographers. 24: 175-192.

Cresswell T. (2010a) Mobilities I: Catching up. Progress in Human Geography 35: 550558.

Cresswell T. (2010b) Towards a politics of mobility Environment and Planning D: Society and Space 28: 17-31.

Cresswell T. (2012) Mobilities II: Still. Progress in Human Geography 36: 645-653.

Cresswell T. (2013) Citizenship in Worlds of Mobility. In: Söderström O, Randeria S, Ruedin D, et al. (eds) Critical Mobilities. Lausanne: EPFL Press.

Cresswell T. (2014) Mobilities III. Progress in Human Geography 38: 712-721.

Creswell T. (2006) On the Move: Mobility in the modern western world. London: Routledge.

Creutzig F, Jochem P, Edelenbosch OY, et al. (2015) Energy and environment. Transport: A roadblock to climate change mitigation? Science (New York, N.Y.) 350: 911.

Cupples J and Ridley E. (2008) Towards a heterogeneous environmental responsibility: sustainability and cycling fundamentalism. Area 40.

Deleuze G. (1988) Spinoza : practical philosophy, San Francisco: San Francisco : City Lights Books.

Deleuze G. (1992) Postscript on the Societies of Control. October 59: 3-7.

Deleuze G. (1994) Difference and Repetition, New York: Columbia University Press.

Deleuze G and Guattari F. (1987) A thousand plateus: capitalism and schizophrenia, London: University of Minnesota Press. 
Dewsbury JD and Thrift N. (2005) 'Genesis Eternal': After Paul Klee1. 89-108.

Dhawan R, Hensley R, Padhi A, et al. (2019) Mobility's second great inflection point. Available at: https://www.mckinsey.com/industries/automotive-andassembly/our-insights/mobilitys-second-great-inflection-point.

Dixon DP. (2014) The way of the flesh: life, geopolitics and the weight of the future. Gender, Place \& Culture 21: 136-151.

Doughty K and Murray L. (2016) Discourses of Mobility: Institutions, Everyday Lives and Embodiment. Mobilities 11: 303-322.

Elliot A. (2016) Gender. In: Salazar NB and Jayaram K (eds) Keywords of mobility: critical engagements. New York, NY: Berghahn Books.

Esson J, Noxolo P, Baxter R, et al. (2017) The 2017 RGS-IBG chair's theme: decolonising geographical knowledges, or reproducing coloniality? Area 49: 384388.

Fastenrath S and Braun B. (2018) Lost in Transition? Directions for an Economic Geography of Urban Sustainability Transitions. Sustainability 10: 2434.

Ferreira Da Silva D. (2013) To Be Announced. Social Text 31: 43-62.

Ferreira da Silva D. (2017a) 1 (life) $\div 0$ (blackness) $=\infty-\infty$ or $\infty / \infty$ : On Matter Beyond the Equation of Value. e-flux 79: 1-11.

Ferreira Da Silva D. (2017b) Speculations on a Transformative Theory of Justice. Hearings: The Online Journal of Countour Biennale.

Frello B. (2008) Towards a Discursive Analytics of Movement: On the Making and Unmaking of Movement as an Object of Knowledge. Mobilities 3: 25-50.

Furness Z. (2010) One Less Car: Bicycling and the Politics of Automobility, Philadelphia, PA: Temple University Press.

Gabrys J. (2014) Powering the Digital: From Energy Ecologies to Electronic Environmentalism. In: Maxwell R, Raundalen J and Vestberg NL (eds) Media and the Ecological Crisis. New York and London: Routledge, 3-18.

García-Olivares A, Solé J and Osychenko O. (2018) Transportation in a 100\% renewable energy system. Energy Conversion and Management 158: 266-285.

Garrett BL. (2014) Undertaking recreational trespass: urban exploration and infiltration. Transactions of the Institute of British Geographers 39: 1-13.

Garrett BL and Hawkins H. (2013) And Now For Something Completely Different ... Thinking Through Explorer Subject-Bodies : A Response to Mott and Roberts. Antipode: 1-22.

Geels FW. (2012) A socio-technical analysis of low-carbon transitions: introducing the multi-level perspective into transport studies Journal of Transport Geography 24: 471-482.

Geels FW. (2014) Regime Resistance against Low-Carbon Transitions: Introducing Politics and Power into the Multi-Level Perspective. Theory, Culture \& Society.

Gibson K. (2014) Thinking around what a radical geography 'must be'. Dialogues in Human Geography 4: 283-287.

Gilmore RW. (2017) Abolition Geography and the Problem of Innocence. In: Johnson GT, \& Lubin, A. (ed) Futures of black radicalism. London: Verso, 225-240.

Golub A. (2015) Moving Beyond Fordism: "Complete Streets" and the changing political economy of urban transportation. In: Zavestoski S and Agyeman J (eds) 
Incomplete Streets: Processes, Practices, and Possibilities. New York: Routledge 36-53.

Golub A, Hoffmann ML, Lugo AE, et al. (2016) Bicycle Justice and Urban Transformation: Biking for all?, Florence: Taylor and Francis.

Goodwin KJ. (2010) Reconstructing Automobility: The Making and Breaking of Modern Transportation. Global Environmental Politics 10.

Gopal P. (2019) Insurgent Empire: Anticolonial Resistance and British Dissent, London Verso

Gorman-Murray A. (2009) Intimate mobilities: emotional embodiment and queer migration. Social \& Cultural Geography 10: 441-460.

Grosz E. (2012) The Nature of Sexual Difference. Angelaki: Journal of the Theoretical Humanities 17: 69-93.

Grosz E. (2017) The Incorporeal: Ontology, Ethics, and the Limits of Materialism, New York: Columbia University Press.

Gustafson P. (2001) Roots and Routes. Environment and Behaviour 33: 667-686.

Halberstam J. (2011) The queer art of failure, Durham [NC: Duke University Press.

Halberstam J. (2013) The Wild Beyond: With and for the Undercommons. In: Harney S and Moten F (eds) The Undercommons: Fugitive Planning \& Black Study. New York: Minor Compositions.

Hannam K, Sheller M and Urry J. (2006) Editorial: Mobilities, Immobilities and Moorings. Mobilities 1: 1-22.

Haraway D. (2004) The Haraway reader, New York ; London: Routledge.

Haraway D. (2016) Staying with the trouble: making kin in the Chthulucene, Durham, North Carolina: Duke University Press.

Harney S and Moten F. (2013) The Undercommons: Fugitive Planning \& Black Study, New York: Minor Compositions.

Harvey D. (2017) 'Listen, Anarchist!' A personal response to Simon Springer's 'Why a radical geography must be anarchist. Dialogues in Human Geography 7: 233-250.

Hatton J. (2018) MARS Attacks! A Cautionary Tale from the UK on the Relation between Migration and Refugee Studies (MARS) and Migration Control. Movements 4.

Hickman R and Banister D. (2007) Looking over the horizon: Transport and reduced CO2 emissions in the UK by 2030. Transport Policy 14: 377-387.

Hickman R, Hall P and Banister D. (2013) Planning more for sustainable mobility. Journal of Transport Geography 33: 210-219.

Hird MJ and Clark N. (2013) 'Deep Shit'. O-Zone: A Journal of Object-Oriented Studies. Holden E, Gilpin G and Banister D. (2019) Sustainable Mobility at Thirty. Sustainability 11.

hooks b. (2003) Teaching Community: A Pedagogy of Hope, New York; London: Routledge

Hopkins D, Higham J, Orchiston C, et al. (2019) Practising academic mobilities: Bodies, networks and institutional rhythms. The Geographical Journal: 1-13.

Huber MT. (2013) Lifeblood: Oil, Freedom, and the Forces of Capital London: University of Minnesota Press.

Huff H and Ralph K. (2014) The reason fewer US women cycle than the Dutch is not what you think it is The Guardian, . The Guardian. 
Hyndman J. (2013) The (Geo)Politics of Mobility. In: Staeheli LA, Kofman E and Peake L (eds) Mapping Women, Making Politics: Feminist Perspectives on Political Geography. Abingdon, Oxon: Routledge Ltd, 169-184.

Imrie R. (2000) Disability and discourses of mobility and movement. Environment and Planning A 32: 1641-1656.

Jackson ZI. (2013) Animal: New Directions in the Theorization of Race and Posthumanism. Feminist Studies 39.

Jensen A. (2011) Mobility, Space and Power: On the Multiplicities of Seeing Mobility. Mobilities 6: 255-271.

Jones JP, Leitner H, Marston SA, et al. (2017) Neil Smith's Scale. Antipode 49: 138-152.

King R. (2012) Geography and Migration Studies: Retrospect and Prospect. Population, Space and Place 18: 134-153.

Kirby V. (2011) Quantum Anthropologies: Life at Large, Durham and London: Duke University Press.

Koglin T. (2014) Vélomobility and the politics of transport planning. GeoJournal.

Koglin T and Rye T. (2014) The marginalisation of bicycling in Modernist urban transport planning. Journal of Transport \& Health 1: 214-222.

Kunz S. (2016) Privileged Mobilities: Locating the Expatriate in Migration Scholarship. Geography Compass 10: 89-101.

Kwan M-P and Schwanen T. (2016) Geographies of Mobility. Annals of the American Association of Geographers 106: 243-256.

Lawhon M and Murphy JT. (2012) Socio-technical regimes and sustainability transitions: Insights from political ecology. Progress in Human Geography 36: 354-378.

Lee D. (2015) The Unbearable Weight of Irresponsibility and the LIghtness of Tumbleweeds: Cumulative irresponsibility in neoliberal streetscapes. In: Zavestoski S and Agyeman J (eds) Incomplete Streets: Processes, Practices, and Possibilities. New York: Routledge 77-93.

Lovell H. (2019) Policy failure mobilities. Progress in Human Geography 43: 46-63.

Lucas K. (2004) Towards a 'social welfare' approach to transport. In: Lucas K (ed) Running on Empty: Transport, social exclusion and environmental justice. Bristol: Policy Press.

Lucas K, Mattioli G, Verlinghieri E, et al. (2016) Transport poverty and its adverse social consequences. Proceedings of the Institution of Civil Engineers - Transport 169: 353-365.

Lucas K, van Wee B and Maat K. (2015) A method to evaluate equitable accessibility: combining ethical theories and accessibility-based approaches. Transportation 43: 473-490.

Lugo AE. (2012) Planning for diverse use/rs: ethnographic research on bikes, bodies, and public space in LA. Kroeber Anthropological Society papers 101: 49-65.

Lugo AE. (2013a) Body-City-Machines: Human Infrastructure for Bicycling in Los Angeles. Anthropology. University of California Irvine, 244.

Lugo AE. (2013b) CicLAvia and human infrastructure in Los Angeles: ethnographic experiments in equitable bike planning. Journal of Transport Geography 30: 202207. 
Manderscheid K. (2016) Who does the move? Affirmation or deconstruction of the solitary mobile subject. In: Grieco M, Endres M, Manderscheid K, et al. (eds) The Mobilities Paradigm : Discourses and Ideologies. London: Routledge.

Manderscheid K, Schwanen T and Tyfield D. (2014) Introduction to Special Issue on 'Mobilities and Foucault'. Mobilities 9: 479-492.

Martens K. (2012) Justice in transport as justice in accessibility: applying Walzer's 'Spheres of Justice' to the transport sector. Transportation 39: 1035-1053.

Massey D. (1993) Power-Geometry and a Progressive Sense of Place. In: Bird J, Curtis B, Putnam T, et al. (eds) Mapping the futures: local cultures, global change. London;New York;: Routledge, 59-69.

Massey D. (2005) For Space, London: Sage.

Mbembe A. (2018) The Idea of a borderless world. Africaisacountry.

McCann E. (2011a) Veritable inventions: cities, policies and assemblage. Area 43: 143147.

McCann EJ. (2011b) Urban Policy Mobilities and Global Circuits of Knowledge: Toward a Research Agenda. Annals of the Association of American Geographers 101: 107-130.

McCormack DP. (2017) Elemental infrastructures for atmospheric media: On stratospheric variations, value and the commons. Environment and Planning D: Society and Space 35: 418-437.

McKinsey. (2019) Snapshots of the global mobility revolution. Available at: https://www.mckinsey.com/industries/automotive-and-assembly/ourinsights/snapshots-of-the-global-mobility-revolution.

McKittrick K. (2014) The Last Place They Thought Of. In: Gieseking JJ and Mangold W (eds) The People, Place, and Space Reader. Oxon: Routledge.

McKittrick K. (2015a) Axis, Bold as Love: On Sylvia Wynter, Jimi Hendrix, and the Promise of Science. In: McKittrick K (ed) Sylvia Wynter: On Being Human as Praxis. Durham and London: Duke University Press, 106-123.

McKittrick K. (2015b) Sylvia Wynter: On Being Human as Praxis. In: McKittrick K (ed) Sylvia Wynter: On Being Human as Praxis. Durham and London: Duke University Press, 106-123.

McKittrick K. (2017) The Algorithm and the Song Feminist Theory Workshop. Duke University, Durham, USA.

Merriman P. (2009) Automobility and the Geographies of the Car. Geography Compass 3/2: 586-599.

Merriman P. (2014) Mobilities I: Departures. Progress in Human Geography 39: 87-95.

Merriman P. (2015) Mobilities II: Cruising. Progress in Human Geography.

Merriman P. (2016) Mobilities III. Progress in Human Geography 41: 375-381.

Merriman P. (2018) Molar and molecular mobilities: The politics of perceptible and imperceptible movements. Environment and Planning D: Society and Space: 026377581877697.

Mignolo WD. (2015) Sylvia Wynter: What Does It Mean to Be Human? In: McKittrick K (ed) Sylvia Wynter: On Being Human as Praxis. Durham and London: Duke University Press, 106-123.

Mills CW. (2017) Black rights/white wrongs : the critique of racial liberalism, New York, NY: Oxford University Press. 
Mott C and Roberts S. (2013a) Difference Really Does Matter: A Reply to Garrett and Hawkins. Antipode.

Mott C and Roberts S. (2013b) Not Everyone Has (the) Balls: Urban Exploration and the Persistence of Maculinist Geography. .

Mullen C and Marsden G. (2016) Mobility justice in low carbon energy transitions. Energy Research \& Social Science 18: 109-117.

Murphy JT. (2015) Human geography and socio-technical transition studies: Promising intersections. Environmental Innovation and Societal Transitions 17: 73-91.

Nash C. (2000) Performativity in practice: some recent work in cultural geography. Progress in Human Geography 24: 653-664.

Nawyn SJ. (2010) Gender and Migration: Integrating Feminist Theory into Migration Studies. Sociology Compass 4: 749-765.

Neimanis A and Walker RI. (2014) Weathering: Climate Change and the "Thick Time" of Transcorporeality. Hypatia 29: 558-575.

Nikolaeva A, Adey P, Cresswell T, et al. (2019) Commoning mobility: Towards a new politics of mobility transitions. Transactions of the Institute of British Geographers 44: 346-360.

O'Lear S. (2016) Climate science and slow violence: A view from political geography and STS on mobilizing technoscientific ontologies of climate change. Political Geography 52: 4-13.

Olson E. (2015) Geography and ethics I: Waiting and urgency. Progress in Human Geography 39: 517-526.

Peake L and Sheppard E. (2014) The Emergence of Radical/Critical Geography within North America. ACME: An International E-Journal for Critical Geographies 13: 305-327.

Peck J. (2010) Constructions of neoliberal reason, Oxford: Oxford University Press.

Peck J. (2011) Geographies of policy: From transfer-diffusion to mobility-mutation. Progress in Human Geography 35: 773-797.

Peck J and Theodore N. (2010) Mobilizing policy: Models, methods, and mutations. Geoforum 41: 169-174.

Pedwell C and Whitehead A. (2012) Affecting feminism: Questions of feeling in feminist theory. Feminist Theory 13: 115-129.

Peet R. (2000) Celebrating thirty years of radical geography. Environment and Planning A 32: 951-953.

Pereira RHM, Schwanen T and Banister D. (2016) Distributive justice and equity in transportation. Transport Reviews 37: 170-191.

Pesses MW. (2010) Automobility, Vélomobility, American Mobility: An Exploration of the Bicycle Tour. Mobilities 5: 1-24.

Peters D. (2013) Gender and Sustainable Urban Mobility. Sustainable Urban Mobility: Global Report on Human Settlements. Nairobi: UN Habitat.

Pignarre P and Stengers I. (2011) Capitalist Sorcery: Breaking the Spell, Basingstoke Palgrave Macmillan

Povinelli E. (2006) The Empire of Love: Toward a Theory of Intimacy, Geneology, and Carnality London: Duke University Press.

Povinelli E. (2016) Geontologies : a requiem to late liberalism, Durham: Duke University Press. 
Prince R. (2017) Local or global policy? Thinking about policy mobility with assemblage and topology. Area 49: 335-341.

Puar J. (2006) Mapping US Homonormativities. Gender, Place \& Culture 13: 67-88.

Puar J. (2011) 'I would rather be a cyborg than a goddess' Intersectionality, Assemblage, and Affective Politics. Transversal Texts.

Puar J. (2017) Hands Up, Don't Shoot! The New Inquiry.

Puar JK. (2005) Queer Times, Queer Assemblages. Social Text 23: 121-140.

Pucher J and Buehler R. (2010) Walking and Cycling for Healthy Cities. Built Environment 36: 391-414.

Pulido L. (2016) Geographies of race and ethnicity II. Progress in Human Geography 41: 524-533.

Rajé F and Saffrey A. (n.d.) 'The Value of Cycling'. University of Birmingham and Phil Jones Associates.

Rankine C. (2015) Citizen: An American Lyric, London: Pengiun Books.

Rink BM and Gamedze AS. (2015) Mobility and the City Improvement District: Frictions in the Human-capital Mobile Assemblage. Mobilities 11: 643-661.

Robinson J. (2015) 'Arriving at' Urban Policies: The Topological Spaces of Urban Policy Mobility. International Journal of Urban and Regional Research 39: 831-834.

Saldanha A. (2016) Scale, Difference and Universality in the Study of Race. Postcolonial Studies 18: 326-335.

Sallis JF. (2016) New evidence for the role of transportation in health. The Lancet Public Health 1: e38-e39.

Salter MB. (2013) To Make Move and Let Stop: Mobility and the Assemblage of Circulation. Mobilities 8: 7-19.

Schapendonk J, van Liempt I, Schwarz I, et al. (2018) Re-routing migration geographies: Migrants, trajectories and mobility regimes. Geoforum.

Scholten C, Friberg T and Sandén A. (2012) Re-Reading Time-Geography from a Gender Perspective: Examples from Gendered mobility. Tijdschrift voor Economische en Sociale Geografie 103: 584-600.

Schwanen T. (2015a) Automobility In: Wright JD (ed) The International Encyclopedia of Social and Behavioral Sciences 2nd Edition ed. Oxford Elsevier.

Schwanen T. (2015b) Beyond instrument: smartphone app and sustainable mobility. EJTIR 15.

Schwanen T. (2015c) Geographies of transport I: Reinventing a field? Progress in Human Geography.

Schwanen T. (2016) Geographies of transport II. Progress in Human Geography 41: 355364.

Schwanen T. (2017) Geographies of transport III. Progress in Human Geography 42: 463-472.

Shell J. (2018) Verkehr, or Subversive Mobility: Recovering Radical Transportation Geographies from Language. Human Geography 11: 11-29.

Sheller M. (2015) Uneven Mobility Futures: A Foucauldian Approach. Mobilities 11: 1531.

Sheller M. (2018) Mobility Justice: The Politics of Movement in an Age of Extremes, London: Verso. 
Sheller M and Urry J. (2006) The new mobilities paradigm. Environment \& planning A. 38: 207-226.

Silvey R. (2004) Power, difference and mobility: feminist advances in migration studies. Progress in Human Geography 28: 490-506.

Sims R. RS, F. Creutzig, X. Cruz-Núñez, M. D’Agosto, D. Dimitriu, M. J. Figueroa Meza, L. Fulton, S. Kobayashi, O. Lah, A. McKinnon, P. Newman, M. Ouyang, J. J. Schauer, D. Sperling, and G. Tiwari, . (2014) Transport. In: Edenhofer O, R. Pichs-Madruga, Y. Sokona, E. Farahani, S. Kadner, K. Seyboth, A. Adler, I. Baum, S. Brunner, P. Eickemeier, B. Kriemann, J. Savolainen, S. Schlömer, C. von Stechow, T. Zwickel and J.C. Minx (ed) Climate Change 2014: Mitigation of Climate Change. Contribution of Working Group III to the Fifth Assessment Report of the Intergovernmental Panel on Climate Change. Cambridge, United Kingdom and New York, NY, USA.: Cambridge University Press.

Smart MJ, Ralph KM, Taylor BD, et al. (2014) Honey, Can You Pick-Up Groceries on Your Way Home? Analyzing activities and travel among students and in nontraditional households. In: Center UoCT (ed). Los Angeles: University of California Los Angeles.

Söderström O, Randeria S, Ruedin D, et al. (2013a) Of Mobilities and Moorings: Critical Perspectives. In: Söderström O, Randeria S, Ruedin D, et al. (eds) Critical Mobilities London: Routledge.

Söderström O, Randeria S, Ruedin D, et al. (2013b) Critical Mobilities. Lausanne: EPFL Press.

Spinney J. (2016) Fixing Mobility in the Neoliberal City Cycling Policy and Practice in London as a Mode of Political Economic and Biopolitical Governance. Annals of the Association of American Geographers 106: 450-458.

Springer S. (2014) Why a radical geography must be anarchist. Dialogues in Human Geography 4: 249-270.

Stehlin J. (2014) Regulating Inclusion: Spatial Form, Social Process, and the Normalization of Cycling Practice in the USA. Mobilities 9: 21-41.

Stehlin J. (2015) Cycles of investment: bicycle infrastructure, gentrification, and the restructuring of the San Francisco Bay Area. Environment and Planning A 47: 121-137.

Stein P. (2015) Why are bike lanes such heated symbols of gentrification. The Washington Post. Washington.

Szeman I and Boyer D. (2017) Energy humanities: an anthology, Baltimore: Johns Hopkins University Press.

Temenos C and McCann E. (2013) Geographies of Policy Mobilities. Geography Compass 7: 344-357.

Temenos C, Nikolaeva A, Schwanen T, et al. (2017) Theorizing Mobility Transitions. 7: 113.

Tyfield D. (2014) Putting the Power in 'Socio-Technical Regimes' - E-Mobility Transition in China as Political Process. Mobilities 9: 585-603.

Urry J. (2004) The 'System' of Automobility. Theory, Culture \& Society 21: 25-39.

Uteng TP. (2009) Gender, ethnicity, and constrained mobility: insights into the resultant social exclusion. Environment and Planning A 41: 1055-1071. 
Uteng TP and Lucas K. (2017) Urban Mobilities in the Global South, Milton: Routledge Ltd.

Vergragt P, Wells P and Nieuwenhuis P. (2017) The Business of Sustainable Mobility: From Vision to Reality: Taylor and Francis.

Waitt G and Welland L. (2017) Water, skin and touch: migrant bathing assemblages. Social \& Cultural Geography: 1-19.

Walks A. (2014) Stopping the 'War on the Car': Neoliberalism, Fordism, and the Politics of Automobility in Toronto. Mobilities: 1-21.

Walsh D, Valestrand H, Gerrard S, et al. (2013) Gendered mobilities in the North: Advancing an international comparative perspective. Norsk Geografisk Tidsskrift 67: 260-265.

Walters W. (2018) Aviation as deportation infrastructure: airports, planes, and expulsion. Journal of Ethnic and Migration Studies 44: 2796-2817.

Weheliye AG. (2014) Habeas Viscus: Racializing Assemblages, Biopolitics, and Black Feminist Theories of the Human, Durham and London: Duke University Press.

Whatmore S. (2013) Earthly Powers and Affective Environments: An Ontological Politics of Flood Risk. Theory, Culture \& Society 30: 33-50.

Wood A. (2015) The Politics of Policy Circulation: Unpacking the Relationship Between South African and South American Cities in the Adoption of Bus Rapid Transit. Antipode 47: 1062-1079.

Woodcock J, Edwards P, Tonne C, et al. (2009) Public health benefits of strategies to reduce greenhouse-gas emissions: urban land transport. Lancet 374: 1930-1943.

Wylie J. (2005) A single day's walking: narrating self and landscape on the South West Coast Path. Transactions of the Institute of British Geographers 30: 234-247.

Wynter S. (2001) Towards the Sociogenic Principle: Fanon, Identity, the Puzzle of Conscious Experience, and What It Is Like to Be "Black". In: Duran-Cogan MF and Gomez-Moriana A (eds) National Identities and Sociopolitical Changes in Latin America. London: Routledge.

Wynter S. (2003) Unsettling the Coloniality of Being/Power/Truth/Freedom: Towards the Human, After Man, Its Overrepresentation - An Argument. The New Centennial Review 3: 257-337.

Yusoff K. (2018) A Billion Black Anthropocenes or None, Minneapolis: University of Minnesota

Zavestoski S and Agyeman J. (2015) Incomplete Streets: Processes, Practices, and Possibilities, New York: Routledge

\section{Notes}

\footnotetext{
${ }^{i}$ Lovell (2019) for example argues for the inclusion of 'failed' policies in the study of policy mobilities. While there is discussion of how failure is framed through its relations with immobility and relations of power, there is less engagement with the dualisms and hierarchies of value that underpin notions of 'success' or 'failure'.
} 
ii It is hard to imagine a form of human mobility that relies entirely on solar, wind, water currents or topography without the input of some energies derived from prior deaths (e.g fossil fuel derived energy and materials) or metabolism of more recent life (organism-derived materials and energy). For example, despite advertising food protein made from only air and sunshine, the production of Solein (https://solarfoods.fi/bioprocess/) requires microbial death. 